\title{
УДК 664.681.6
}

DETERMINATION OF THE EFFECT OF FLOUR PRODUCED FROM AMARANTIC SEED AND GUM ARABIC «FIBREGUM» ON THE DOUGH STRUCTURING PROCESS IN THE DEVELOPMENT OF HIGH BIOLOGICAL VALUE CRACKERS TECHNOLOGY

\section{ВИЗНАЧЕННЯ ВПЛИВУ БОРОШНА 3 НАСІННЯ АМАРАНТУ ТА ГУМІАРАБІКУ «FIBREGUM» НА ПРОЦЕС СТРУКТУРОУТВОРЕННЯ ТІСТА ПРИ РОЗРОБЦІ ТЕХНОЛОГІЇ КРЕКЕРІВ ПІДВИЩЕНОЇ БІОЛОГІЧНОЇ ЦІННОСТІ}

Dzyhar O.O. / Дзизар 0.O.

PhD student / acnipaнm

ORCID: 0000-0003-0681-6345

National University of Food Technologies, Kyiv, Volodymyrska, 68, 01601 Національний університет харчових технологій, Київ, Володимирська, 68, 01601 Obolkina V.I. / Оболкіна B.I. d.t.s., prof. / d.m.н., проф. ORCID: 0000-0002-1319-5017

National University of Food Technologies, Kyiv, Volodymyrska, 68, 01601 Національний університет харчових технологій, Київ, Володимирська, 68, 01601

Анотація. У статті розглянуто особливість використання борошна з насіння амаранту у технології крекерів підвищеної біологічної цінності. Доведено, щуо амарантове борошно має дуже низькі технологічні властивості. На підставі фаринографічних досліджень встановлено, щзо водопоглинальна здатність композитних борошняних сумішей зі збільшенням масової частки амарантового борошна зростає, збільшується розрідження тіста та час утворення, зменшується еластичність.

Обгрунтована доиільність використання гуміарабіку «Fibreguт B тм» для корегування структурно-механічних властивостей крекерного тіста. Завдяки здатності гуміарабіку до гідрофобних взаємодій з клейковинним комплексом пшеничного борошна та утворенням міцних структурних зв'язків у дисперсійному середовищі внаслідок зв'язування вільної вологи харчовими волокнами полісахариду спостерігалося збільшення загальної $i$ пружної деформації тіста, граничної напруги зсуву та зменшення адгезійної міџності.

За результатами оптимізаџії рещеептурного складу тіста для крекерів з 50\% заміною борошна з насіння амаранту встановлено, що рекомендована гранична напруга зсуву тіста досягається дозуванням 3,0 \% гуміарабіку до кількості борошна. На підставі результатів досліджень розроблено технологію крекерів "Амарантове диво» та "Амарантова магія» 3 додаванням борошна $з$ насіння амаранту та гуміарабіку «Fibreguт $B$ тм» 3 підвищеною біологічною изіністю, подовженим терміном придатності до споживання.

Ключові слова: пшеничне борошно, борошно з насіння амаранту, біологічна цінність, гуміарабік, крекери, технологія

Вступ. Пріоритетним напрямком у кондитерської галузі $\epsilon$ створення технологій нового асортименту виробів з підвищеною харчовою та біологічною цінністю завдяки використання рослинної сировини с підвищеним вмістом біологічно активних речовин (БАР). Незмінним попитом на споживчому ринку користуються крекери - борошняні вироби з крихкою, шаруватою структурою. Крекери мають добрі смакові властивості, але недоліком є низький вміст білку та невелика кількість БАР. Тому виникає необхідність корегування їх хімічного складу завдяки використанню нетрадиційних видів борошна, зокрема борошна iз насіння амаранту (БНА) [1]. Насіння амаранту $є$ цінним джерелом 
мінерального комплексу, має високий вміст вітамінів: $\mathrm{C}, \mathrm{E}, \mathrm{B}_{1}, \mathrm{~B}_{2}, \mathrm{~B}_{9}, \mathrm{PP}, \mathrm{A}, \mathrm{D}$ та володіє високою антиоксидантною здатністю [2, 3].

БНА містить підвищений вміст білку (14-17\%), який добре збалансований за амінокислотним складом. Сумарний білок амаранту на 28-35\% складається 3 незамінних амінокислот, які $є$ регуляторами обмінних процесів в організмі людини. Зокрема кількість лізину майже у 2,5 рази та метіоніну у 1,5 рази більше ніж у пшеничному борошні, Фракційний склад БНА суттєво відрізняється від пшеничного. Більша частина білків (50-70\%) складається 3 альбумінів та глобулінів, менша частина містить проламіни та глютеліни [4]. Це має суттєво впливати на технологічні властивості композитних сумішей 3 пшеничним борошном. Насіння та борошно 3 насіння різного подрібнення використовується у хлібопекарській, кондитерській та харчоконцентратній промисловості. Науковцями розроблені технології різноманітних продуктів, які забезпечують підвищений вміст білку, вітамінів та мінеральних речовин $[5,6]$. Вченими було приділено багато уваги щодо створення здобного печива, кексів, бісквітів із застосуванням амарантового борошна 3 метою підвищення біологічної цінності виробів $[1,7]$. Отже, використання амарантового борошна дасть можливість отримати продукцію із збалансованим хімічним складом.

Метою роботи було визначення технологічних властивостей БНА, композитних сумішей з пшеничним борошном, визначення оптимальних умов приготування тіста при виробництві нового асортименту крекерів 3 підвищеною біологічною цінністю та подовженим терміном придатності їх до споживання.

\section{Матеріали та методи дослідження.}

Під час проведення досліджень використовували борошно пшеничне вищого сорту, борошно 3 насіння амаранту, гуміарабік «Fibregum В тм $_{\text {» }}$ (виробник компанія «Nexira», Франція). Дослідження технологічних властивостей модельних зразків борошняних суспензій визначали на фаринографі Брабендера; зміну структурно-механічних властивостей тіста на приладі «Структурометр»; оптимізацію рецептурного складу крекеру та математичну обробку експериментальних даних проводили за допомогою багатофакторного експерименту.

Результати наукових досліджень.

Основну роль у формуванні структурно-механічних властивостей крекерного тіста відіграють нерозчинні білкові речовини пшеничного борошна - гліадинова і глютеїнова фракції, від кількості та якості яких залежать його технологічні властивості. Тому застосування амарантового борошна у створенні нового асортименту крекерів вимагає визначення його впливу на показники якості композитної суміші з пшеничним борошном. Для проведення досліджень застосовували різне дозування амарантового борошна в композитної суміші від $10 \%$ до 50 \%. Встановлено, що із збільшенням кількості амарантового борошна погіршуються структурно-механічні властивості клейковини пшеничного борошна, відбувається збільшення розтяжності та показника деформації клейковини. Структурні характеристики модельних зразків тіста на основі композитних сумішей пшеничного та 
амарантового борошна визначали на фаринографі Брабенденра (табл. 1).

На підставі аналізу фаринограм замішування модельних зразків тіста було встановлено, що водопоглинальна здатність композитної суміші зі збільшенням масової частки амарантовго борошна (10-50\%) зростає, що пов'язано з гідрофільністю високомолекулярних сполук (білків, клітковини).

Під час утворення тіста збільшується його розрідження та час утворення, зменшується еластичність, тобто амарантове борошно має дуже низькі технологічні властивості.

Таблиця 1

Характеристика фаринограм замісу модельних зразків тіста на основі композитних сумішей пшеничного та амарантового борошна

\begin{tabular}{|l|c|c|c|c|c|c|}
\hline \multirow{2}{*}{ Назва показників } & \multicolumn{5}{|c|}{$\begin{array}{c}\text { Значення показників модельних зразків тіста 3 } \\
\text { різним дозуванням амарантового борошна }\end{array}$} \\
\cline { 2 - 7 } & контроль & $10 \%$ & $15 \%$ & $20 \%$ & $25 \%$ & $50 \%$ \\
\hline $\begin{array}{l}\text { Водопоглинальна } \\
\text { здатність, \% }\end{array}$ & 55,0 & 56,0 & 57,5 & 59,5 & 62,5 & 68,5 \\
\hline Час утворення тіста, хв & 2,0 & 2,0 & 2,0 & 3,5 & 4,0 & 4,3 \\
\hline Стабільність, хв & 0,0 & 0,5 & 2,0 & 2,0 & 2,0 & 2,0 \\
\hline Розрідження, од. фар & 80,0 & 85,0 & 90,0 & 95,0 & 105,0 & 125,0 \\
\hline Еластичність тіста, мм & 29 & 25 & 23 & 21 & 20 & 18 \\
\hline
\end{tabular}

Додавання амарантового борошна погано впливало на структурномеханічні властивості, структура тіста була крихкою та одночасно липкою, неоднорідною, що унеможливлювало процес ламінування та формування тістових напівфабрикатів.

Для корегування структурних властивостей тістового напівфабрикату у рецептурний склад вводили додатковий структуроутворювач - камедь акації

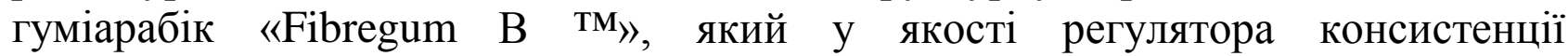
застосовується у різних харчових системах: виконує пребіотичну функцію, сприяє підтримці імунітету людини за рахунок стимулювання росту і розвитку його біфідо-і лактобактерій, має антиоксидантні властивості [8].

Аналіз фаринограм замішування показав, що в модельних зразках тіста 3 додаванням гуміарабіку зменшувалася водопоглинальна здатність та розрідження тіста, збільшувалася його еластичність і час утворення (табл. 2). На підставі проведених досліджень зроблено висновок про доцільність додавання гуміарабіку для корегування структурних властивостей крекерного тіста 3 додаванням амарантового борошна.

Для визначення структурно-механічних властивостей тіста гуміарабік вносили від 1,5 до 3,5 \% до загальної кількості борошна. За результатами досліджень структурно-механічних властивостей тіста 3 додаванням амарантового борошна та гуміарабіку встановлено збільшення загальної i пружної деформації (табл. 3), граничної напруги зсуву, та зменшення адгезійної міцності. 
Таблиця 2

Характеристика фаринограм замішування модельних зразків тіста 3 додаванням амарантового борошна та гуміарабіку

\begin{tabular}{|l|c|c|c|}
\hline \multirow{2}{*}{\multicolumn{1}{|c|}{ Показники }} & \multicolumn{3}{|c|}{ Значення показників тіста } \\
\cline { 2 - 4 } & $350 \%$ & з додаванням гуміарабіку \\
\cline { 3 - 4 } & $\mathrm{AБ}$ & $1,5 \%$ & $3,5 \%$ \\
\hline Водопоглинальна здатність, \% & 68,5 & 65,2 & 62,7 \\
\hline Час утворення тіста, хв & 4,3 & 5,0 & 5,5 \\
\hline Стабільність, хв & 2,0 & 2,0 & 2,5 \\
\hline Розрідження, од.фар & 125,0 & 105 & 90 \\
\hline Еластичність тіста, мм & 18 & 23 & 27 \\
\hline
\end{tabular}

Таблиця 3

Структурно-механічні властивості тіста для крекерів із додаванням амарантового борошна та гуміарабіку

\begin{tabular}{|c|c|c|c|c|c|}
\hline Зразок тіста & $\begin{array}{l}\Delta \mathrm{H}_{\text {заг, }} \\
\text { од. пр. }\end{array}$ & $\begin{array}{l}\Delta \mathrm{H}_{\text {пл. }} \\
\text { од. пр. }\end{array}$ & $\begin{array}{l}\Delta \mathrm{H}_{\text {пр., }} \\
\text { од. пр. }\end{array}$ & $\begin{array}{c}\Delta \mathrm{H}^{\mathrm{siдн}} \text { пл. } \\
\%\end{array}$ & $\begin{array}{c}\Delta \mathrm{H}^{\text {відн }}{ }_{\text {пр. }} \\
\%\end{array}$ \\
\hline $\begin{array}{l}\text { Без додавання } \\
\text { гуміарабіку }\end{array}$ & 6,25 & 5,52 & 0,73 & 88,32 & 11,68 \\
\hline \multicolumn{6}{|c|}{3 додаванням гуміарабіку } \\
\hline $1,5 \%$ & 7,75 & 6,71 & 0,95 & 86,58 & 12,13 \\
\hline $2,0 \%$ & 8,32 & 7,04 & 1,18 & 84,61 & 14,18 \\
\hline $3,5 \%$ & 8,95 & 7,50 & 1,45 & 83,80 & 16,20 \\
\hline
\end{tabular}

Збільшення граничної напруги зсуву та пружної деформації тіста 3 додаванням гуміарабіку можна пояснити утворенням міцних структурних зв'язків у дисперсійному середовищі, що пов'язано зі зв'язуванням вільної вологи харчовими волокнами полісахариду. Крім того, молекула гуміарабіку має поліелектролітну природу та виявляє здатність до гідрофобних взаємодій 3 клейковинним комплексом з утворенням нековалентних зв’язків. Це, вірогідно, впливає на властивості клейковини пшеничного борошна та сприяє підвищенню пружно-пластичних властивостей тіста.

Оптимальну кількість гуміарабіку та технологічні параметри приготування тістового напівфабрикату визначали на підставі проведеного математичного моделювання процесу приготування тіста методом багатофакторного експерименту та отриманої математичної моделі за допомогою методу крутого сходження Бокса-Уілсона. Метою оптимізації було отримання тістового напівфабрикату 3 певними структурно-механічними властивостями. Критерієм оптимальності вибрана гранична напруга зсуву $(Y)$, яка досягається співвідношенням рецептурних компонентів і масової частки вологи тіста. На підставі проведеної оптимізації отримано рівняння регресії:

$$
\mathrm{Y}=4,29+1,02 \mathrm{X}_{1}-0,33 \mathrm{X}_{2}+0,29 \mathrm{X}_{3}
$$

де $X_{1}$ - кількість гуміарабіку, $X_{2}$ - масова частка вологи тіста, $X_{3}$ тривалість замішування. 
Визначено, що оптимальна концентрація гуміарабіку становить 3,0 \% до маси борошна, масова частка вологи тіста становить $34 \%$, тривалість замішування тіста -45 хвилин.

За результатами досліджень науково обгрунтовано та розроблено технології крекерів «Амарантове диво» й «Амарантова магія». Вироби мають подовжений термін зберігання завдяки антиоксидантній активності борошна 3 амаранту та гуміарабику «Fibregum B тм .

\section{Висновки}

На підставі проведених досліджень науково обгрунтовано доцільність

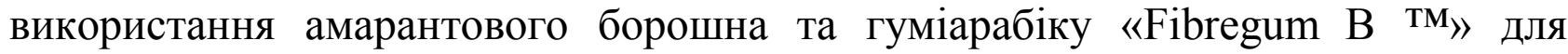
створення крекерного тіста 3 певними структурно-механічними властивостями. Визначено оптимальні параметри приготування тіста та розроблено технологію крекерів підвищеної смакової та біологічної цінності з подовженим терміном придатності до споживання.

Література

1. Фахретдинова Д. Р., Нигматьянов А. А., Миронова И. В. Использование амарантовой муки и молочной сыворотки для обогащения мучных кондитерских изделий // Известия Оренбургского аграрного государственного университета. - 2017. - № 4. - С. 260-262.

2. Venskutonis P. R., Kraujalis P. Nutritional components of amaranth seeds and vegetables: a review on composition, properties, and uses // Comprehensive Reviews in Food Science and Food Safety. - 2013. - Vol. 12. - P. 381-412.

3. Pazinatto C., Malta L. G., Pastore G. M., Netto F. M. Antioxidant capacity of amaranth products: effects of thermal and enzymatic treatments // Food Science and Technology. - 2013. - Vol. 33, № 3. - P. 485-493.

4. Шмалько H. А. Сравнительный анализ белково-протеиназного комплекса хлебопекарной пшеничной амарантовой муки // Техника и технология пишевых производств. - 2011. - №2. - С. 84-88.

5. Martinez C. S., Ribotta P. D., Añón M. C., León A. E. Effect of amaranth flour (Amaranthus mantegazzianus) on the technological and sensory quality of bread wheat pasta // Food Sciens and Technology Internetional. - 2014. -Vol. 20, № 2. P. 127-135.

6. Beswa D., Dlamini N. R., Siwela M., Amdnsdu E. D., Kdlanisi U. Effect of Amaranth addition on the nutritional composition and consumer acceptability of extruded provitamin A-biofortified maize snacks // Food Science and Technology. 2016. - Vol. 36, № 1. - P. 30-39.

7. Иоргачева Е. Г., Макарова О. В., Котузаки Е. Н., Капетула С. М. Бисквитные полуфабрикаты на основе муки из зерновых и крупяных культур // Технологія і безпечність родуктів харчування. 2012. №1(18). С. 79-82.

8. Cherbut C., Michel C., Raison V., Kravtchenko T., Meanse S. Acacia gum is a bifidogenic dietary fiber with high digestive tolerance in healthy humans // Microbial. Ecol. Health. Dis. - 2003. - № 15. - P. 43-50. 


\section{References:}

1. Fahretdinova D. R., Nigmatyanov A. A., Mironova I. V. (2017). Ispolzovanie amarantovoj muki i molochnoj syvorotki dlya obogasheniya muchnyh konditerskih izdelij [Using of amaranth flour and whey for the enrichment of flour confectionery products] in Izvestiya Orenburgskogo agrarnogo gosudarstvennogo universiteta [News of the Orenburg Agrarian State University], № 4, pp. 260-262.

2. Venskutonis P. R., Kraujalis P. (2013). Nutritional components of amaranth seeds and vegetables: a review on composition, properties, and uses in Comprehensive Reviews in Food Science and Food Safety, Vol. 12, pp. 381-412.

3. Pazinatto C., Malta L. G., Pastore G. M., Netto F. M. (2013). Antioxidant capacity of amaranth products: effects of thermal and enzymatic treatments in Food Science and Technology, Vol. 33, № 3, pp. 485-493.

4. Shmalko N. A. (2011) Sravnitelnyj analiz belkovo-proteinaznogo kompleksa hlebopekarnoj pshenichnoj amarantovoj muki [Comparative analysis of the protein-proteinase complex of baking wheat flour and amaranth flour] in Tehnika i tehnologiya pishevyh proizvodstv [Technique and technology of food production], №2, pp. 84-88.

5. Martinez C. S., Ribotta P. D., Añón M. C., León A. E. (2014). Effect of amaranth flour (Amaranthus mantegazzianus) on the technological and sensory quality of bread wheat pasta in Food Sciens and Technology Internetional, Vol. 20, № 2, P. 127-135.

6. Beswa D., Dlamini N. R., Siwela M., Amdnsdu E. D., Kdlanisi U. (2016). Effect of Amaranth addition on the nutritional composition and consumer acceptability of extruded provitamin A-biofortified maize snacks in Food Science and Technology,Vol. 36, № 1, pp. 30-39.

7. Iorgacheva E. G., Makarova O. V., Kotuzaki E. N., Kapetula S. M. (2012) Biskvitnye polufabrikaty na osnove muki iz zernovyh i krupyanyh kultur [Semi-finished biscuits based on flour from cereals] in Tehnologiya i bezpechnist roduktiv harchuvannya [Food technology and safety], №1(18), pp. 79-82.

8. Cherbut C., Michel C., Raison V., Kravtchenko T., Meanse S. (2003). Acacia gum is a bifidogenic dietary fiber with high digestive tolerance in healthy humans in Microbial. Ecol. Health. Dis, № 15, pp. 43-50.

Abstract. The peculiarity of the use of amaranth seed flour in technology of high biological value crackers is considered in the article. It is proved that amaranth flour has very low technological properties. On the basis of pharinographic studies it has been established that with the increasing of mass fraction of amaranth flour the water absorption capacity of composite flour mixtures increases, increases the dough dilution and the formation time, decreases elasticity.

The expediency of using gum arabic «Fibregum B» for correction of the structural and mechanical properties of cracker dough is substantiated. Due to the ability of gum arabic to hydrophobic interactions with the gluten complex of wheat flour and the formation of strong structural bonds in the dispersion medium due to the binding of free moisture by the dietary fibers of the polysaccharide, an increase in total and elastic deformation of the dough and the shear stress and the decrease in adhesive strength. was observed.

According to the results of optimization of the recipe composition of the dough for crackers with $50 \%$ replacement of flour made from amaranth seeds, it is established that the recommended maximum shear stress of the dough is achieved by dosing $3.0 \%$ of gum arabic to the amount of flour. Based on the results of the researches, the technology of crackers «Amaranth miracle» and «Amaranth magic» made of amaranth seed flour and gum arabic «Fibregum B» with increased biological value and extended shelf life, was developed.

Keywords: wheat flour, amaranth flour, biological value, gum arabic, crackers, technology

Дата надходження статті: 07.10.2019 (C) Дзигар O.O. 